\title{
Integrasi SMOTE dan Ensemble AdaBoost Untuk Mengatasi Imbalance Class Pada Data Bank Direct Marketing
}

\author{
Amin Nur Rais ${ }^{1}$, Agus Subekti ${ }^{2}$ \\ ${ }^{1}$ STMIK Nusa Mandiri Jakarta \\ 2Pusat Penelitian Elektronik dan Telekomunikasi \\ Lembaga IImu Pengetahuan Indonesia (LIPI) \\ e-mail: 1aminnurraiskleca@gmail.com, 2agus.subekti@lipi.go.id
}

\begin{abstract}
Abstrak
Kampanye pemasaran produk bank secara langsung dapat dibantu dengan adanya teknologi informasi. Dengan terus bertambahnya data dan penggunaan teklogi informasi, data yang didapatkan dapat dimanfaatkan lebih maksimal untuk membuat keputusan. Tetapi, data yang ada menunjukkan ketidak seimbangan pada kelasnya sehingga dapat menurunkan prediksi dalam mengambil keputusan karena cenderung menghasilkan prediksi kelas mayoritas daripada kelas minoritas. Dengan menyeimbangkan data dengan menggunakan pra pemprosesan SMOTE, kelas data dapat menjadi lebih seimbang. Pada penelitian ini, diusulkan model dengan menggunakan pra proses SMOTE dan ensemble AdaBoost yang dikombinasikan dengan algoritma klasifikasi untuk mendapatkan nilai akurasi yang terbaik. Algoritma klasifikasi yang digunakan yaitu Naïve Bayes, SVM, dan Decision Tree. Hasil penelitian menunjukkan bahawa model klasifikasi dengan model SMOTE dan AdaBoost yang digabungkan dengan algoritma klasifikasi naïve bayes memiliki nilai akurasi terendah dengan nilai akurasi 88,3\%, sendangkan SVM memiliki akurasi 89,68\%, dan pada model klasifikasi dengan Decision Tree memperoleh hasil klasifikasi terbaik dengan nilai akurasi 92,25\%.
\end{abstract}

Kata kunci: Kelas tidak seimbang, smote, ensemble adaboost, pemasaran langsung

\begin{abstract}
Direct bank product marketing campaigns can be helped by the existence of information technology. As data continues to grow and the use of information technology, the data obtained can be utilized more optimally to make decisions. However, existing data shows an imbalance in the class so that it can reduce predictions in making decisions because it tends to produce the prediction of the majority class rather than the minority class. By balancing data using SMOTE pre-processing, data classes can become more balanced. In this study, a proposed model using the SMOTE pre-process and the AdaBoost ensemble is combined with a classification algorithm to get the best accuracy value. The classification algorithm used is Naïve Bayes, SVM, and Decision Tree. The results showed that the classification model with the SMOTE and AdaBoost models combined with the naïve bayes classification algorithm had the lowest accuracy value with an accuracy value of $88.3 \%$, whereas SVM had an accuracy of $89.68 \%$, and the classification model with the Decision Tree obtained the best classification results with an accuracy value of $92.25 \%$.
\end{abstract}

Kata kunci: Unbalanced class, smote, adaboost ensemble, direct marketing

\section{Pendahuluan}

Mengenalkan produk secara langsung telah umum digunakan untuk berbagai industri, salah satunya industry perbankan. Dalam mengenalkan produk secara langsung, bank dapat melakukan analisa pasar dengan memanfaatkan ruang teknologi informasi yang dapat membantu dalam mengambil keputusan (Abbas, 2015). Kampanye pemasaran produk bank secara langsung sangat berguna untuk 
menawarkan produk baru kepada calon pelanggan. Dengan melakukan analisa data pemasaran bank, dapat digunakan untuk memilih jenis pemasaran yang dilakukan. Kampanye pemasaran dapat dilakukan melalui email, telepon, dan email langsung kepada calon pelanggan yang memungkinkan calon pelanggan dapat memutuskan untuk mengambil produk yang ditawarkan atau tidak. Proses analisa dapat dilakukan dengan teknologi informasi yang didukung dengan terus bertambahnya informasi data pelanggan untuk mendukung pengambilan keputusan (Moro, Laureano, \& Cortez, 2011)

Dengan bertambahnya waktu, jumlah data yang masuk terus bertambah. Data yang ada memberikan informasi tentang konsumen yang berguna untuk membuat keputusan di masa mendatang. Akan tetapi, terjadi ketimpangan respon dari konsumen terhadap penawaran yang dilakukan. Sehingga terjadi ketidak seimbangan kelas pada data. Permasalahan ketidak seimbangan kelas (Imbalance Class) menyebabkan hasil klasifikasi lebih condong ke class mayoritas. Dimana jumlah class negative (mayoritas) lebih besar dari class positive (minoritas) yang dapat menurunkan kinerja model prediksi.

Dalam menangani dataset yang tidak seimbang, terdapat 3 pendekatan yang dapat dilakukan, yaitu pendekatan level data, level algoritmik, dan pendekatan dengan menggabungkan metode. Pada pendekatan level data, mencakup berbagai teknik resampling untuk memperbaiki distribuasi kelas pada data. Pada level algoritmik, dilakukan proses penyesuaian operasi algoritma yang ada untuk menjalankan pengklasifikasian (classifier) agar lebibih konduktif terhadap klasifikasi kelas minoritas. Sedangkan pada pendekatan gabungan (ensemble), terdapat 2 ensemble-learning paling popular, yaitu boosting dan bagging. Pada pendekatan algoritma dan ensemble memiliki tujuan yang sama, yaitu memperbaiki algoritma pengklasifikasi tanpa mengubah data, sehingga dapat dianggap ada 2 pendekatan saja, yaitu pendekatan level data dan pendekatan level algoritma. Dengan membagi menjadi 2 pendekatan dapat mempermudah dalam proses perbaikan.

$$
\text { Untuk mengatasi ketidak }
$$
seimbangan kelas, dapat digunakan pendekatan teknik sampling over-sampling, under sampling, dan kombinasi keduanya (Perbankan \& No, 2016). Salah satu teknik sampling yang digunakan adalah dengan melakukan pendekatan level data dengan teknik SMOTE (Synthetic Minority Oversampling Technique) (Putri, 2015).

Dalam mengolah data yang asimetris, digunakan algoritma SMOTE dan Rotation Forest (PCS)-J48 dimana SMOTE digunakan untuk memodifikasi data dan meningkatkan keakuratan prediksi. Dengan menggunakan PCA-J48 mendapatkan nilai akurasi yang tinggi dengan nilai $90.81 \%$ dan sensivisitas $81,23 \%$. Namun sensifitas metode BayesNet dan PCA-RandomTree memiliki nilai sensitivitas lebih tinggi dari PCA-J48 (Ruangthong \& Jaiyen, 2015).

Dalam memprediksi respon pelanggan, dengan menerapkan empat pengklasifikasian, yaitu Multilayer Perceptron Neural Network (MLPNN), Decision Tree (C4.5), Regresi Logistik, dan Random Forest (RF). Penelitian ini menggambarkan bahwa klasifikasi dengan RF menjadi klasifikasi paling produktif dalam kemampuan prediksi dengan nilai akurasi $87 \%$. Sedangkan fitur utama dari pelanggan yang kemungkinan besar berlangganan berjangka jika pelanggan menghabiskan lebih lama dalam panggilan dengan pendidikan minimal sekolah menengah (Asare-Frempong \& Jayabalan, 2017).

Pada penelitian ini dilakukan dengan pendekatan teknik SMOTE yang dikombinasikan dengan ensemble AdaBoost dengan algoritma J48, SVM, dan Naïve Bayes.

\section{Metode Penelitian}

Paper ini menggunakan dataset public yang diambil dari kaggle repository tentang pemasaran langsung yang dilakukan oleh bank di Portugis dengan 41.188 data yang terdiri dari 20 atribut dan 2 kelas. dataset ini berkaitan dengan pemasaran secara langsung yang dilakukan oleh lembaga perbankan Portugis kepada calon pelanggannya. Pemasaran ini didasarkan pada panggilan telepon. Biasanya perlu lebih dari satu kali proses penawaran kepada calon konsumen yang sama untuk memastikan apakah akan menggunakan prosuk yang ditawarkan atau tidak. 
Dataset ini terbagi menjadi 4 bagian (table 1), yaitu data client, releated with the last contact of the current campaign, other atribut, dan social and economic context attributes.

Tabel 1. Ringkasan Dataset

\begin{tabular}{|r|l|l|}
\hline $\begin{array}{r}\text { N } \\
0\end{array}$ & Attribute Name & Attribut Type \\
\hline \multicolumn{3}{|c|}{ Data Client } \\
\hline 1 & Age & Numeric \\
\hline 2 & Job & Categorical \\
\hline 3 & Marital & Categorical \\
\hline 4 & Education & Categorical \\
\hline 5 & Default & Categorical \\
\hline 6 & Housing & Categorical \\
\hline 7 & Loan & Categorical \\
\hline \multicolumn{3}{|c|}{ Related With The Last Contact Of The } \\
\multicolumn{3}{|c|}{ Current Campaign } \\
\hline 8 & Contact & Categorical \\
\hline 9 & Month & Categorical \\
\hline 10 & Day_of_week & Categorical \\
\hline 11 & Duration & Numeric \\
\hline \multicolumn{3}{|c|}{ Other Attributes } \\
\hline 12 & Campaign & Numeric \\
\hline 13 & Pdays & Numeric \\
\hline 14 & Previous & Numeric \\
\hline 15 & Poutcome & Categorical \\
\hline Social And Economic Context Attributes \\
\hline 16 & Emp.var.rate & Numeric \\
\hline 17 & Cons.price.idx & Numeric \\
\hline 18 & cons.conf.idx & Numeric \\
\hline 19 & Euriborn3m & Numeric \\
\hline 20 & Nr.employed & Numeric \\
\hline \multicolumn{3}{|c|}{ Output } \\
\hline 21 & y & Binary \\
\hline \multicolumn{3}{|c|}{} \\
\hline
\end{tabular}

Dataset yang digunakan akan diuji dengan berbagai pemodelan klasifikasi dengan teknik K-Fold Validation (10). Dimana proses pengujian dilakukan dengan menguji pendekatan level data SMOTE dengan ensemble AdaBoost yang dipadukan dengan algoritma Naïve Bayes, SVM, dan Decision Tree.

Sebagai evaluasi model dilakukan dengan menggunakan akurasi dari model pengklasifikasian yang diajukan. Kemudian hasil dari masing - masing pengujian disajikan untuk melihat hasilnya dan menentukan hasil yang terbaik. Dari hasil pengujian yang terbaik, akan dibandingkan dengan hasil dari model pada penelitian sebelumnya (Lawi, Velayaty, \& Zainuddin, 2018).

\section{Hasil dan Pembahasan}

Penelitian dilakukan dengan menggunakan laptop dengan processor Intel Core i5-2520M CPU @2.50GHz dengan RAM 4GB, dan system operasi Windos 7 Professional 64bit. Sedangkan dalam melakukan eksperimen didukung dengan tools WEKA 3.8.1.

Penelitian ini menggunakan dataset public yang diambil dari $\mathrm{UCl}$ Machine Learning Repository tentang pemasaran langsung yang dilakukan oleh bank di Portugis dengan 41.188 data yang terdiri dari 20 atribut dan 2 kelas. dataset ini berkaitan dengan pemasaran secara langsung yang dilakukan oleh lembaga perbankan Portugis kepada calon pelanggannya. Pemasaran ini didasarkan pada panggilan telepon. Biasanya perlu lebih dari satu kali proses penawaran kepada calon konsumen yang sama untuk memastikan apakah akan menggunakan prosuk yang ditawarkan atau tidak.

Dalam proses penelitian, digunakan 20 feature yang terbagi menjadi 4 bagian (table 1), yaitu data client, releated with the last contact of the current campaign, other atribut, dan social and economic context attributes dengan 2 kelas, dimana kelas yes terdiri dari 464 data, dan no 3.655 data.

\subsection{Preprocessing Data}

Preprocessing data dilakukan untuk menangani ketidak seimbangan kelas dengan menggunakan teknik SMOTE. Dimana teknik SMOTE berguna untuk menghasilkan data yang lebih baik dan efektif untuk menangani ketidak seimbangan kelas yang mengalami overfitting pada proses teknik over-sampling untuk kelas minoritas (positif). SMOTE menciptakan sebuah contoh dari kelas minoritas sintetis yang beroperasi di ruang fitur daripada ruang data. Dengan menduplikasi contoh kelas minoritas, teknik SMOTE menghasilkan contoh sintetis baru dengan melakukan ekstrapolasi sampel minoritas yang ada dengan sampel acak 
yang diperoleh dari nilai $\mathrm{k}$ tetangga terdekat. Dengan hasil sintetis pada contoh yang lebih dari kelompok minoritas, sehingga mampu memperluas area keputusan mereka untuk minoritas.

Prinsip dari Metode SMOTE adalah dengan menambah jumlah data kelas minor agar setara dengan kelas mayor dengan cara membangkitkan data buatan. Data buatan atau sintesis tersebut dibuat berdasarkan $\mathrm{k}$-tetangga terdekat (k-nearest neighbor) (Terhadap, Tidak, Pada, Model, \& Jamu, 2013). Jumlah k-tetangga terdekat ditentukan dengan mempertimbangkan kemudahan dalam melaksanakannya. Pembangkitan data buatan yang berskala numerik berbeda dengan kategorik. Data numerik diukur jarak kedekatannya dengan jarak Euclidean sedangkan data kategorik lebih sederhana yaitu dengan nilai modus. Perhitungan jarak antar contoh kelas minor yang peubahnya berskala kategorik dilakukan dengan rumus Value Difference Metric (VDM) yaitu :

$\Delta(X, Y)=W_{x} W_{Y} \sum_{i=1}^{N} \delta\left(X_{i}, Y_{i}\right)^{r}$

Dengan :

$\Delta(X, Y)$ : Jarak antara amatan $\mathrm{X}$ dengan $\mathrm{Y}$

$W_{x} W_{Y} \quad$ : Bobot amatan (dapat diabaikan)

$\mathrm{N} \quad$ : Banyaknya peubah penjelas

R : Bernilai 1 (jarak Manhattan) atau 2 (jarak Euclidean)

$\delta\left(X_{i}, Y_{i}\right)^{r}$ : Jarak antar kategori, dengan rumus

$\delta\left(V_{1}, V_{2}\right)=\sum_{i=1}^{n}\left|\frac{C_{1 i}}{C_{1}}-\frac{C_{2 i}}{C_{2}}\right|^{k}$

Dengan :

$\delta\left(V_{1}, V_{2}\right) \quad$ : Jarak antara nilai $\mathrm{V} 1$ dan V2

C1i : Banyaknya V1 yang termasuk kelas i

C2i : Banyaknya V2 yang termasuk kelas $\mathrm{i}$

I : Banyaknya kelas; $\mathrm{I}=1,2, \ldots, \mathrm{m}$

C1 : Banyaknya nilai 1 terjadi

C2 : Banyaknya nilai 2 terjadi

$\mathrm{N} \quad$ : Banyaknya kategori

K : Konstanta (biasanya 1)
Dengan meneapkan SMOTE, meminimalisir ketidak seimbangan kelas dengna membangkitkan data sintesis kelas minoritas dari 451 menadi 3.654 (gambar 2)

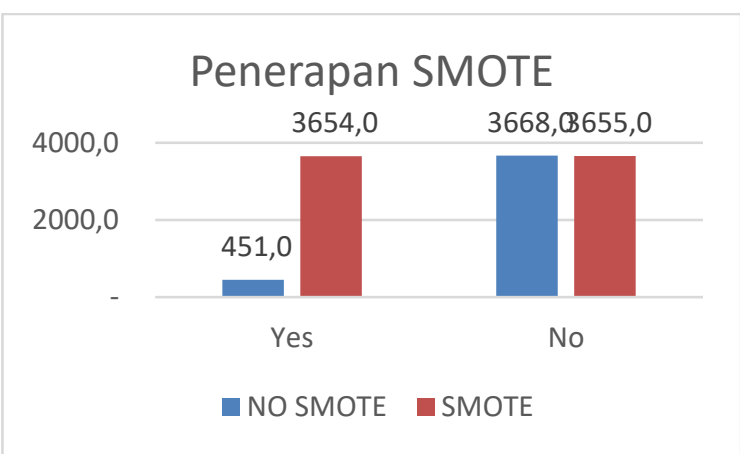

Gambar 2. Penerapan SMOTE

3.2. Eksperimen dan Pengujian Model

3.2.1. Metode Ensemble Adaptive Boosting (AdaBoost)

Boosting merupakan pendekatan pada machine learning untuk meningkatkan peraturan prediksi yang akurat dengan menggabungkan banyak peraturan yang relatif lemah dan tidak akurat (Nurzahputra \& Muslim, 2017). Adaptive boosting (adaboost) merupakan salah satu dari beberapa varian pada algoritma boosting (Liu, Tian, Li, \& Zhang, 2015). AdaBoost menjadi ensemble learning yang sering digunakan pada algoritma AdaBoost. AdaBoost dan variannya telah berhasil diterapkan pada beberapa bidang karena dasar teorinya yang kuat, prediksi yang akurat, dan kesederhanaan yang besar dengan langkah - langkah sebagai berikut:

a. Input : Suatu kumpulan kumpulan sample penelitian dengan lable $\{(x i$, yi), ..., $(X n, X n)\}$, suatu component learn algoritma dengan jumlah perputaran $\mathrm{T}$

b. Initialize : Bobot suatu sample pelatihan $W_{i}^{1}=1 / N$, untuk semua $\mathrm{i}$ $=1, \ldots, \mathrm{N}$

c. Do for $t=1, \ldots, T$

1. Gunakan component learn algoritma untuk melatih suatu komponen klasifikasi ht, pada sample bobot pelatihan.

2. Hitung kesalahan pelatihannya pada $\quad h_{t}: \varepsilon_{t}=\sum_{i=1}^{w} w_{i}^{t}, y_{i} \neq$ $h_{t}\left(x_{i}\right)$

3. Tetapkan bobot untuk component classifier $h_{t}==$ $a_{t}=\frac{1}{2} \operatorname{In}\left(\frac{1-\varepsilon_{t}}{\varepsilon_{t}}\right)$ 
4. Update bobot sample pelatihan $w_{i}^{t+1}=\frac{w_{i}^{t} \exp \left\{-a_{t} y_{t} h_{t}\left(x_{i}\right)\right\}}{c_{t}}, i=$ $1, \ldots, N C_{t} \quad$ adalah suatu konstanta normalisasi

Output $f(x)=\operatorname{sign}\left(\sum_{t=1}^{T} a_{t} h_{t}(x)\right)$

\subsubsection{Algoritma Naïve Bayes}

Naïve bayes merupakan teknik probabilistik klasifikasi berdasarkan teorema Bayes dengan asumsi independensi diantara variabel predictor (Anam \& Santoso, 2018). Secara sederhana, pengelompokan Naïve Bayes menganggap adanya suatu fitur tertentu dalam sebuah kelas tidak terkait dengan adanya fitur lainnya. Teorema Bayes memberikan cara untuk menghitung posterior probability $\mathrm{P}(\mathrm{C} \mid \mathrm{X})$ dari $\mathrm{P}(\mathrm{C}), \mathrm{P}$ $(\mathrm{X})$ dan $\mathrm{P}(\mathrm{X} \mid \mathrm{C})$ dengan persamaan berikut:

$P(C \mid X)=\frac{P(X \mid C) P(C)}{(X)}$

(3)

Dengan :

$\mathrm{P}(\mathrm{C} \mid \mathrm{X})$ : Posterior Probability kelas (C, target) yang diberikan predictor ( $X$, atribut)

sebelumnya

$\mathrm{P}(\mathrm{C}) \quad$ : Probabilitas kelas

$P(X \mid C)$ : Kemungkinan yang merupakan probabilitas predictor kelas yang diberikan

sebelumnya

$P(X) \quad$ : Probabilitas predictor

\subsubsection{Algoritma SVM}

Support vector machine (SVM) adalah classifier biner yang secara linier memisahkan kedua kelas dengan menemukan margin maksimum yang memisahkan bidang hyper antara dua kelas (Lin, Yang, \& Zuo, 2010). Hyper plane pemisah margin maksimum ditemukan dengan menyelesaikan masalah optimisasi quadratic programming (QP). Keuntungan terbesar SVM datang ketika data dipisahkan secara nonlinier. Dalam hal ini, SVM membuat data dapat dipisahkan secara linear dengan bantuan fungsi kernel. Fungsi kernel adalah pemetaan pola input data ke beberapa ruang dimensi tinggi sehingga titik data menjadi terpisah secara linear. Dalam praktiknya, tidak mendefinisikan pemetaan titik-titik data secara implisit, melainkan secara eksplisit didefinisikan sebagai produk dalam antara titik-titik data menurut dipisahkan dalam ruang dimesi tinggi. Berbagai jenis fungsi kernel dapat digunakan sebagai Gaussian kernel, polynomial kernel dll. Makalah ini kami ambil dari kernel polynomial. Polynomial kernel didefinisikan sebagai

$k(\vec{x}, \vec{z})=\left(\vec{z}^{T} \vec{x}+C\right)^{n}$

Dimana $\mathrm{n}$ adalah ururan dari kernel, dan c adalah konstanta yang memungkinkan untuk menukarkan pengaruh urutan yang lebih tinggi dan urutan yang lebih rendah.

\subsubsection{Algortitma Decision Tree}

Decision tree dengan algoritma J48 merupakan salah satu metode klasifikasi yang menggunakan representasi struktur pohon (tree) dimana setiap node merepresentasikan atribut, cabangnya merepresentasikan nilai dari atribut, dan daun merepresentasikan kelas (Ardiansyah Sembiring, Fitri Larasati Sibuea, Sapta, Studi Sistem Informasi, \& Royal, 2018). Node yang paling atas dari decision tree disebut sebagai root. Dimana dilakukan langkah - langkah sebagai berikut untuk membangun pohon keputusan ;

1. Membentuk decission system yang terdiri dri attribut kondisi dan atribut keputusan. Memperlihatkan sebuah contoh decision system yang pada penelitian ini. la hanyaterdiri dari $\mathrm{n}$ objek, E1, E2, E3, E4,.....,En dan attribute kondisi yaitu penjualan, pembelian, stok gudang, serta beban usaha. Sedangkan profit adalah decision attribute

2. Hitung jumlah data kolom, jumlah data berdasarkan anggota atribut hasil dengan syarat tertentu. Untuk proses pertama syaratnya masih kosong

3. Pilih atribut sebagai Node

4. Buat cabang untuk tiap tiap anggota dari Node

5. Periksa apakah nilai entropy dari anggota Node ada yang bernilai nol. Jika ada, tentukan daun yang terbentuk. Jika seluruh nilai entropy

6. Jika ada anggota Node yang memiliki nilai entropy lebih besar dari nol, ulangi lagi proses dari awal dengan Node sebagai syarat sampai semua anggota dari Node bernilai nol 
Node menjadi atribut dengan nilai gain tertinggi dari atribut yang ada. Untuk menghitung nilai gain suatu atribut digunakan rumus :

$\operatorname{Gain}(S, A)=\operatorname{Entropy}(S)-\sum_{i=1}^{n}\left|\frac{S i}{S}\right| *$
$\operatorname{Entropy}(S i)$

Dengan :
S : Himpunan kasus
A : Atribut
$\mathrm{N} \quad$ : Jumlah partisi atribut $\mathrm{A}$
|Si| : Proporsi Si terhadap S
|S| : Jumlah kasus dalam S

Sementara untuk menghitung nilai Entropy dengan persamaan :

$\operatorname{Entropy}(S)=\sum_{i=1}^{n}-p i * \log _{2} p i$ (6)

Dengan :

$$
\begin{array}{ll}
\mathrm{S} & : \text { Himpunan Kasus } \\
\mathrm{N} & : \text { Jumlah partisi S } \\
\mathrm{Pi} & : \text { Proporsi Si terhadap S }
\end{array}
$$

\subsection{Evaluasi Hasil Kinerja Model Usulan}

Dalam pengevaluasian model digunakan $\mathrm{k}$-fold validation (10 fold) dan confusion matrix dengan membandingkan hasil klasifikasi yang dilakukan oleh system dengan hasil klasifikasi yang sebenarnya. Pengukuran akurasi dengan confusion matrix dapat dilihat pada table 1 (Bisri, 2015).

Table 2. Confusion Matrix

\begin{tabular}{|l|l|l|l|}
\hline & \multicolumn{3}{|c|}{ Class Prediksi } \\
\hline \multirow{3}{*}{ Class Aktual } & & \multicolumn{1}{|c|}{ Yes } & no \\
\cline { 2 - 4 } & Yes & TP & FN \\
\cline { 2 - 4 } & No & FP & TN \\
\hline
\end{tabular}

Dengan formula penghitungan sebagai berikut :

$$
\begin{aligned}
& \text { Akurasi }=\frac{T P+T N}{T P+F P+F N+T N} \\
& \text { Sensitivity }=\text { Recall }=T P \text { Rate }=\frac{T P}{T P+F N} \\
& \text { Specifity }=\text { TNRate }=\frac{T N}{F P+T N} \\
& \text { FPRare }=\frac{F P}{F P+T N}
\end{aligned}
$$

$$
\begin{aligned}
& \text { Precision }=\frac{T P}{T P+F P} \\
& G-\text { mean }=\sqrt{\text { Sensitivity } \times \text { Specifity }} \\
& F-\text { Measure }=\frac{2 \times \text { Recall } \times \text { Precision }}{(\text { Recall }+ \text { Precision })} \\
& A U C=\frac{1+\text { TPRate }+ \text { FPRate }}{2}
\end{aligned}
$$

Pengujian dilakukan dengan menguji pendekatan level data SMOTE dengan ensemble AdaBoost yang dipadukan dengan algoritma Naïve Bayes, SVM, dan Decision Tree (table 3).

Table 3. Hasil Pengujian

\begin{tabular}{|r|l|r|r|r|}
\hline No & Kriteria & NB & SMO & J48 \\
\hline \multirow{2}{*}{1} & Akurasi & 88,3 & 89,6 & 95,7 \\
& $0 \%$ & $8 \%$ & $3 \%$ \\
\hline \multirow{2}{*}{2} & \multirow{2}{*}{ Komputasi } & 7,38 & 1.07 & 886, \\
& & & 4,06 & 79 \\
\hline \multirow{4}{*}{3} & SENSITIVIT & & & \\
& Y & 86,3 & 88,4 & 94,8 \\
& RECALL & $8 \%$ & $5 \%$ & $0 \%$ \\
& TPrate & & & \\
\hline \multirow{2}{*}{4} & SPECIFITY & 90,2 & 90,9 & 96,6 \\
& = TNrate & $2 \%$ & $1 \%$ & $6 \%$ \\
\hline \multirow{2}{*}{5} & FPrate & 9,78 & 9,09 & 3,34 \\
& & $\%$ & $\%$ & $2 \%$ \\
\hline \multirow{2}{*}{6} & Precision & 89,8 & 90,6 & 96,6 \\
& Pro & $9 \%$ & $0 \%$ \\
\hline \multirow{2}{*}{7} & G-Mean & 88,2 & 89,6 & 95,7 \\
& F-M & $7 \%$ & $2 \%$ \\
\hline \multirow{2}{*}{8} & F-Measure & 88,0 & 89,5 & 95,6 \\
& $7 \%$ & $6 \%$ & $9 \%$ \\
\hline \multirow{2}{*}{9} & AUC & 88,3 & 89,6 & 95,7 \\
& & $0 \%$ & $8 \%$ & $3 \%$ \\
\hline
\end{tabular}

Dari hasil klasifikasi dengan mengintegrasikan pendekatan level data SMOTE dan ensemble AdaBoost dari sample dataset bank-marketing diketahui bahwa algoritma J48 memiliki nilai akurasi (gambar 3) dan presisi terbaik dari algoritma SVM dan Naïve Bayes. Tetapi dalam melakukan komputasi, algoritma SVM paling lama, dan Naïve Bayes paling cepat. 


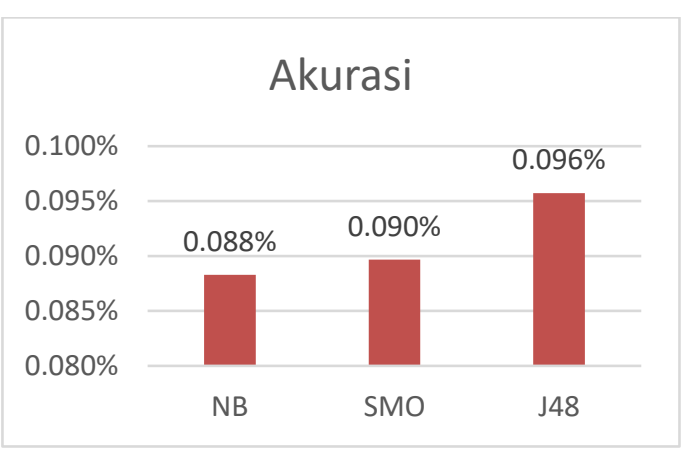

Gambar 3. Perbandingan akurasi

\subsection{Perbandingan Dengan Penelitian Terkait}

Hasil perbandingan dengan penelitian sebelumnya menunjukan bahwa kinerja dari model yang diusulkan memiliki nilai akurasi lebih baik. Dimana pada model yang diusulkan dengan menggunakan SMOTE + AdaBoost + J48 menunjukkan nilai akurasi yang lebih baik. Hasil penelitian ini selanjutnya dapat dijadikan bahan referensi bagi penelitian selanjutnya.

Table 4. Perbandingan Penelitian Terkait

\begin{tabular}{|r|l|c|}
\hline No & \multicolumn{1}{|c|}{ Model } & Akurasi \\
\hline 1 & $\begin{array}{l}\text { SMOTE + Rotation } \\
\text { Forest (PCA)-J48 } \\
\text { (Ruangthong \& Jaiyen, } \\
2015)\end{array}$ & $90,81 \%$ \\
\hline 2 & $\begin{array}{l}\text { partitioning based } \\
\text { method - C4.5 DT (Mitik, } \\
\text { Korkmaz, Karagoz, } \\
\text { Toroslu, \& Yucel, 2017) }\end{array}$ & 74,61\% \\
\hline 3 & $\begin{array}{l}\text { MLPNN, C4.5, Regresi } \\
\text { Logistik and RF (Asare- } \\
\text { Frempong \& Jayabalan, } \\
\text { 2017) }\end{array}$ & $86,8 \%$, \\
\hline 4 & $\begin{array}{l}\text { SMOTE + J48 } \\
\text { (Perbankan \& No, 2016) }\end{array}$ & $93,21 \%$ \\
\hline $\mathbf{5}$ & $\begin{array}{l}\text { SMOTE + AdaBoost + } \\
\text { J48 }\end{array}$ & $\mathbf{9 5 , 7 3 \%}$ \\
\hline
\end{tabular}

\section{Kesimpulan}

Penelitian dilakukan dengan tools WEKA pada dataset pemasaran langsung pada bank untuk membandingkan kinerja dari algoritma Naïve Bayes, SVM, dan Decision Tree dengan pendekatan level data SMOTE dan ensemble AdaBoost. Hasil penelitian menunjukkan bahwa klasifikasi dengan J48 memiliki kemampuan prediksi lebih baik dari Naïve Bayes dan SVM. Metode yang diusulkan dengan pendekatan level data SMOTE dan ensemble AdaBoost dengan algoritma J48 memiliki kemampuan lebih baik dari PCA J48 dan SMOTE dengan SVM.

\section{Referensi}

Abbas, S. (2015). Deposit subscribe Prediction using Data Mining Techniques based Real Marketing Dataset. International Journal of Computer Applications, 110(3), 1-7. https://doi.org/10.5120/19293-0725

Anam, C., \& Santoso, H. B. (2018). Perbandingan Kinerja Algoritma C4 . 5 dan Naive Bayes untuk Klasifikasi Penerima Beasiswa. Jurnal IImiah IImu-IImu Teknik, 8(1), 13-19.

Ardiansyah Sembiring, M., Fitri Larasati Sibuea, M., Sapta, A., Studi Sistem Informasi, P., \& Royal, S. (2018). Analisa Kinerja Algoritma C.45 Dalam Memprediksi Hasil Belajar. Journal of Science and Social Research, 1(February), 73-79. Retrieved from http://jurnal.goretanpena.com/index.ph $\mathrm{p} / \mathrm{JSSR}$

Asare-Frempong, J., \& Jayabalan, M. (2017). Predicting customer response to bank direct telemarketing campaign. 2017 International Conference on Engineering Technology and Technopreneurship, ICE2T 2017, 2017-Janua, 1-4. https://doi.org/10.1109/ICE2T.2017.82 15961

Bisri, A. (2015). Penerapan Adaboost untuk Penyelesaian Ketidakseimbangan Kelas pada Penentuan Kelulusan Mahasiswa dengan Metode Decision Tree. 1(1).

Lawi, A., Velayaty, A. A., \& Zainuddin, Z. (2018). On identifying potential direct marketing consumers using adaptive boosted support vector machine. Proceedings of the 2017 4th International Conference on Computer Applications and Information Processing Technology, CAIPT 2017, 2018-Janua, 1-4. https://doi.org/10.1109/CAIPT.2017.83 20691

Lin, L., Yang, S., \& Zuo, R. (2010). Protein secondary structure prediction based on multi-SVM ensemble. Proceedings 
of 2010 International Conference on Intelligent Control and Information Processing, ICICIP 2010, (PART 2), 356-358.

https://doi.org/10.1109/ICICIP.2010.55 64201

Liu, H., Tian, H. Q., Li, Y. F., \& Zhang, L. (2015). Comparison of four Adaboost algorithm based artificial neural networks in wind speed predictions. Energy Conversion and Management, 92, 67-81. https://doi.org/10.1016/j.enconman.20 14.12.053

Mitik, M., Korkmaz, O., Karagoz, P., Toroslu, I. H., \& Yucel, F. (2017). Data Mining Based Product Marketing Technique for Banking Products. IEEE International Conference on Data Mining Workshops, ICDMW, 552-559. https://doi.org/10.1109/ICDMW.2016.0 085

Moro, S., Laureano, R. M. S., \& Cortez, P. (2011). Using Data Mining for Bank Direct Marketing: An application of the CRISP-DM methodology. 25th European Simulation and Modelling Conference- ESM'2011, (Figure 1), 117-121.
Nurzahputra, A., \& Muslim, M. A. (2017). Peningkatan Akurasi Pada Algoritma C4.5 Menggunakan Adaboost Untuk Meminimalkan Resiko Kredit. Prosiding SNATIF Ke-4, (1), 243-247.

Perbankan, I., \& No, J. G. (2016). Metode Klasifikasi Data Mining dan Teknik Sampling Smote ... (Hairani dkk.). 168-172.

Putri, S. A. (2015). Integrasi SMOTE dan Information Gain pada Naive Bayes untuk Prediksi Cacat Software. 1(2).

Ruangthong, P., \& Jaiyen, S. (2015). Bank direct marketing analysis of asymmetric information based on machine learning. Proceedings of the 2015 12th International Joint Conference on Computer Science and Software Engineering, JCSSE 2015, 93-96.

https://doi.org/10.1109/JCSSE.2015.7 219777

Terhadap, S., Tidak, D., Pada, S., Model, P., \& Jamu, K. (2013). PENERAPAN SYNTHETIC

MINORITY OVERSAMPLING TECHNIQUE. 1(1). 